\title{
Childhood Astrocytic Tumor
}

National Cancer Institute

\section{Source}

National Cancer Institute. Childhood Astrocytic Tumor. NCI Thesaurus. Code C9022.

An astrocytic tumor appearing before the age of twenty one without designation of benign or malignant nor designated location. 